Article

\title{
Inclusive Smart Cities: Beyond Voluntary Corporate Data Sharing
}

\author{
Julien Mercille
}

check for updates

Citation: Mercille, J. Inclusive Smart Cities: Beyond Voluntary Corporate Data Sharing. Sustainability 2021, 13, 8135. https://doi.org/10.3390/ su13158135

Academic Editors: Araz Taeihagh,

Martin De Jong and

Leonidas Anthopoulos

Received: 17 May 2021

Accepted: 13 July 2021

Published: 21 July 2021

Publisher's Note: MDPI stays neutral with regard to jurisdictional claims in published maps and institutional affiliations.

Copyright: (C) 2021 by the author. Licensee MDPI, Basel, Switzerland. This article is an open access article distributed under the terms and conditions of the Creative Commons Attribution (CC BY) license (https:/ / creativecommons.org/licenses/by/ $4.0 /)$.
Geary Institute for Public Policy, School of Geography, University College Dublin, D04V1W8 Belfield, Ireland; julien.mercille@ucd.ie

\begin{abstract}
Smart cities mobilise technologically driven solutions toward urban governance and service delivery. The profitable opportunities and abundance of data made available by cities attract ICT corporations that possess the resources and knowledge to make cities smart. However, this often leads corporate actors to monopolise the data collected and generated. This poses risks for privacy and the ways in which personal data are used and commercialised. Existing work on business-to-government (B2G) data sharing and data collaboratives has explored the technical and organisational issues involved in corporate data sharing with public authorities. However, many studies remain focused on voluntary corporate data releases. This paper argues that the option of compelling companies to share data should be considered more attentively; it is one channel (among many) that has the potential to make cities more inclusive.
\end{abstract}

Keywords: B2G data sharing; data collaboratives; smart cities; data philanthropy

\section{Introduction}

The concept of smart cities refers to the integration of technology, sensors and big data through the Internet of Thing (IoT) into city governance to serve people's needs [1,2]. Smart cities mark the rise in demand for technologically driven solutions in the Global North and South [3] perceived as bringing significant benefits to local governments in terms of service delivery, financial savings and sustainability [4-6]. Such technologies have become important, among other things, due to rising expectations for services to citizens while local jurisdictions face acute budgetary pressures. The rise in demand for technological solutions provides ICT (information communication technology) corporations with profitable opportunities to integrate themselves in smart cities' digital infrastructures and governance through a range of public-private partnerships [7]. Beyond corporate financial rewards, cities also represent rich sources of data for private companies, which are essential to further innovate and improve their products and services [8].

However, smart cities' privatisation of services traditionally provided by local governments and cities poses a number of challenges. Although companies can provide a range of useful technologies, their involvement raises a number of concerns related to privacy and personal data usage [9]. Those worries are especially evident when private firms possess intellectual property rights on the technologies utilised, which they are reluctant to share. This may give rise to privacy breaches, inadequate collection, usage and commercialisation of personal data, as well as surveillance practices that encroach on personal freedoms [10]. Moreover, the monopolisation of technologies by companies implies that little knowledge transfer may happen towards city authorities and actors outside the firm. In other words, a key challenge faced by local governments and cities is that when they enter into publicprivate partnerships, the data generated are often controlled by the private partners. First, the private companies own the machines, sensors and other technological devices used to collect and generate data. Second, once collected, public authorities often do not have the technological resources (knowledge, storage capacity, sharing and analysis resources) and must rely on private companies to conduct those tasks [7]. 
Within this context, smart city authorities face difficult choices about how to provide digital and data-driven solutions to acute problems, as well as to rectify imbalances of power that may arise with ICT corporations [11]. Indeed, smart cities are 'emerging as new battlegrounds over personal data' [11] (p. 7) and face crucial strategic decisions on key issues: Who owns and controls data? Who decides how the abundance of data is collected and used? Additionally, how can cities ensure that data generation and use are conducted in an inclusive manner that does not lead to discrimination, exclusion, and loss of privacy? [11-16].

Compounding the situation, it has been argued that the implementation of smart cities is often too 'top-down', focusing on efficiency gains and optimisation while neglecting the real needs of residents. People are conceived as 'passive sensors' rather than active participants who shape the directions taken by the city [17]. Thus, many have called for investing in human capital and for fostering the participation of citizens in smart cities' decision-making processes [18-22].

Within this context, this paper explores the issue of data sharing between the private sector and public authorities ('business-to-government' or 'B2G' data sharing). The discussion proceeds at a broad conceptual level and aims to inform arguments about the challenges faced by smart cities with respect to data sharing, power imbalances between public authorities and private firms, as well as the participatory inclusion of citizens. It is suggested that mainstream approaches to B2G data sharing focus overly on the needs and interests of the corporate sector but neglect to emphasise that private firms can be compelled to share data with public authorities, even if firms would prefer not to do so. The situation is analogous to taxation: while firms would prefer to lower their tax bill, research goes beyond exploring how the tax code could be made more appealing to corporations and instead focuses on ways to establish more equitable and effective tax collection methods. Secondly, although there are obvious potential public benefits to B2G data sharing, it should be noted that some data sharing between large companies and governments serves to reinforce corporate and state power over ordinary people. In other words, B2G data sharing takes place between entities (business and governments) whose interests are not necessarily aligned with those of citizens, especially in neoliberal times; rather, they follow elite interests. Therefore, B2G is no panacea and must follow democratic principles in order to achieve its declared inclusive objectives. In sum, issues of socio-economic power must be considered in private data exchange [23].

The arguments below are thus broadly situated within critical scholarship on the digital era of capitalism and critical data studies. These literatures have paid attention to the unequal power relationships operating within the digital economy [24-30]. Data collection has become pervasive and highly valuable and the concentration of data within large corporations results in new forms of inequity between companies and consumers and users of digital technologies [31-33].

\section{B2G Data Sharing: Beyond Voluntary Corporate Data Releases}

It is important to contextualise this paper within the large literature on data governance models that seek to democratise data sharing and usage. Indeed, concerns about 'hegemonic data governance models' [34] have led to a range of analytical approaches to make smart cities more inclusive and democratic. This paper focuses on B2G data sharing, public-private partnerships and interactions between private companies and public authorities. However, the paper is situated among, and related to, a number of related frameworks addressing the multiple types of partnerships between public, private and nongovernmental actors, as well as among citizens and data users themselves, to leverage and share data for positive societal impact. Those relevant literatures have produced a number of data governance models [35-37] and labels to refer to data sharing and usage arrangements, including 'data driven social partnerships' [38], 'data collaboratives' [39-42], 'platform cooperatives' [43-49], 'data trusts' [50-52] and 'data philanthropy' [53-55]. The phrase 'data for good' [56] is also used to underline the positive potential of data sharing. 
A number of case studies of individual cities examine in detail alternative data governance schemes that seek with varying degrees of success to democratise digital life [35,36,57-63].

Such initiatives build on arguments to empower citizens and reach 'technological sovereignty' in a datafied world that is political $[27,35,64-67]$ by presenting the possibilities of agency from the 'bottom up' [35,36,50,59,62,63,68-74], 'good data practices' [75] and 'alternative data governance models' [34,61]. As such, a number of typologies and classifications have been presented in the scholarly and grey literatures to conceptualise the diversity of private data sharing practices [34,37,76-81].

A number of contributions do address the potential to compel corporations to share data. In particular, there have been recent explorations of inclusive data sharing examples in cities that question (implicitly or explicitly) digital capitalist structures, surveillance capitalism and 'data governance extractivism' that are aligned with the argument presented here (see below). However, there is also a distinct and significant trend in the mainstream literature that emphasises technical and organisational aspects of data sharing that largely depend on voluntary sharing on the part of corporate data holders. These discussions emphasise ways to 'incentivise' corporate actors to share their data rather than 'requiring' or 'compelling' them to do so; accordingly, they also put substantial effort in demonstrating the benefits of data sharing, as if to convince corporations that benefits will be widely distributed if they share their data.

For example, a conventional approach is to conceive of data access on a continuum from closed to open, as in the Open Data Institute's 'data spectrum' [82] or in the Urban Institute's 'spectrum of data philanthropy' [83]. A range of existing data sharing technical mechanisms and organisational forms are described along the spectrum, each making more or less private data available to the public. For example, McKeever, Greene, MacDonald, Tatian and Jones [83] describe the public accessibility of corporate data by identifying five positions on a continuum from 'most restricted' to 'most accessible': (1) a company/data provider may conduct all the data analysis in-house and then share with the public the insights that emerged from the analysis; (2) a company may bring external researchers into its own network to analyse data and report findings publicly; (3) data providers may work with other data providers to share data among themselves; (4) a data provider may share data with trusted external researchers; (5) a company may allow direct public access to some of its datasets (which are often anonymised before they are released). The OECD presents a similar spectrum of public-private partnerships that corresponds to various levels of corporate data openness vis-à-vis public agencies [84] (see also [77,85]). Others propose a taxonomy of types of data collaboratives according to the types of (technical) mechanisms used to exchange data and who receives private data, including research partnerships, prizes and challenges, application programming interfaces (APIs) and data pooling [86,87]. A sophisticated taxonomy of data collaboratives has also been proposed, based on organisational and technical aspects of data supply (sharing) and demand (usage) resulting in a total of 14 dimensions that describe collaboration [42].

Yet, private companies remain reluctant to share their data. A number of perceived risks and challenges to doing so have been identified. The European Commission outlined economic, organisational, governance, cultural and techno-operational issues $[77,88]$. A review of data partnerships [89] reviewed 35 challenges in four categories: regulatory, organisational, data-related and societal. These obstacles arise both on the supply side (to provide data) and demand side (to receive data). The barriers most frequently cited in the literature include privacy issues (companies are reluctant to share data because it could expose their customers' identity if the data are not anonymised carefully or if there are leaks of information), legal barriers (regulations may be conflicting or lacking with regard to releasing data), prohibitive cost of releasing data (cleaning, organising and reformatting data incurs costs for businesses), technical barriers (there is a need for technical knowledge and equipment to release data adequately), lack of incentives for data providers to share data (factors often mentioned include the risk of losing competitive advantage and com- 
mercial sensitivity), and a lack of clarity on the part of data receivers regarding what data are available, as well as high access costs.

In response, researchers have suggested ways to alleviate the risks businesses face when releasing data. Therefore, the implicit or explicit objective in those approaches is to implement business-friendly conditions that are conducive to private data sharing. In other words, discussions of corporate motivations to share data are centred on companies' needs and interests, but neglect processes whereby firms can be compelled to share data, sometimes at a cost to them. For example, the European Commission $[77,88]$ explains that firms are reluctant to share their data with governments because of possible negative commercial ramifications, including foregone profits, high costs, enhanced regulation, and competition in strategic markets. The Commission is explicit that private firms should see a net benefit in sharing their data, suggesting that we 'should seek a win-win collaboration' and 'mutually beneficial' initiatives between businesses and public authorities [77] (pp. 38-39). Methods to address those barriers are discussed but focus on giving incentives to companies, including monetary (e.g., tax) incentives, investment of public funds to develop trusted technical tools for data sharing, and reputational rewards (corporate social responsibility programmes). Data sharing could also be made compulsory, but compensation would have to be provided to firms, perhaps varying with the scale of the expected social benefits. In fact, the Commission considers a range of compensation mechanisms from public authorities to companies to ensure the latter benefit from data sharing [77].

The priority granted to business interests is also apparent in the Commission's announced principles on B2G data sharing in its communication Towards a Common European Data Space [90] and accompanying staff working document Guidance on Sharing PrivateSector Data in the European Data Economy [91], as well as discussion of those principles by the High-Level Expert Group on business-to-government data sharing [77]. For example, these state that: 'legitimate private-sector interests, notably commercially sensitive information such as trade secrets, are respected'; private companies 'should not be held liable for the quality of the data' shared; 'public-sector bodies may not use private-sector data for commercial purposes or to compete with a company that has a similar offering'; and companies 'should not be required to improve data quality at no cost' [77] (pp. 82, 84).

Similar approaches have been proposed in the academic literature. In her 'data commons regime', Shkabatur argues that private companies should be seen as 'allies' instead of 'adversaries' and believes that private companies' interests can be aligned with the public good: 'Importantly, the idea of a global data commons abandons the adversary stance of current regulatory approaches. Instead of treating data platform companies as hostile entities that should be approached with suspicion, it regards them as collaborators ... Rather, an open-minded collaboration between data platforms and external stakeholders could be in the mutual interests of all the involved parties. If designed properly, it can contribute to the public good without jeopardizing legitimate market interests of data platform companies, and without impinging the privacy rights of platform users.' [81] (p. 384). Others have argued that in order to facilitate data disclosure, we should protect companies' 'brand value' (pp. 1-24, [92]) and that businesses will be incentivised to release data if the public and private benefits of data sharing are explained to them [87] and (pp. 1-24, [92]).

Accordingly, researchers have outlined and explained the benefits resulting from the release of companies' data, assuming that this lack of knowledge impedes B2G data sharing $[77,83,87,88,92]$. These include public services improvements (data exchanges allow for public services to be better designed and delivered), prediction and forecasting (institutions can plan better by anticipating societal trends), impact assessment (big data can help to monitor and evaluate the impacts of policies and decisions), innovation and economic growth (releasing more data can allow more researchers and entrepreneurs to use datasets in novel ways, fostering innovation and economic growth), cost savings (accessing private data may save the public sector the costs of collecting the same data with its own 
limited financial resources), situational awareness and response (data increase the ability to monitor real-world conditions more precisely).

The problem, however, is that for-profit companies have remained slow to share data, because their priority is to increase profits and market share [23]. In fact, they often share data simply because they directly benefit from it [93]. For example, firms gain positive media coverage, build their brand, obtain access to free academic labour, and can potentially hire valuable talent that emerges from partnerships with researchers [94]. Companies can also make direct financial gains by sharing their data for a fee [77,81,85]. A report based on a survey of companies' attitudes to data sharing found that they share data 'to gain insights that support the company's mission' and 'to unlock and demonstrate the value of company data', in addition to supporting philanthropic objectives [95] (p. 7). For instance, data may be shared with academic researchers to demonstrate the value of company data for novel applications. Academic journal articles based on company data help to confirm the reliability and trustworthiness of the data for the company. However, interviews with data researchers suggest that it is unlikely that corporate data can be accessed unless the proposed research is aligned with corporate goals [95]. In short, companies are reluctant to share data, which they see as a corporate asset. Additionally, when they do so, it is often based on self-interest, and may thus be unreliable to meet public needs. Therefore, emphasising the benefits of $\mathrm{B} 2 \mathrm{G}$ data sharing to encourage companies to share data may be less productive than expected.

\section{Inclusive vs. Elitist B2G Data Sharing}

Academic research and practitioners have neglected the potentially interventionist role that governments can take $[96,97]$ to compel the private sector to share data, and to put the conditions in place for this to occur. Moreover, because of the assumption that corporate interests can be aligned with the public good, much effort has been targeted at demonstrating the 'benefits for all' that data sharing could involve. However, this paper suggests that (1) more attention should be paid to possible government interventions to compel companies to share their data and (2) although B2G data sharing can potentially lead to positive outcomes, existing data sharing arrangements reveal that the priorities of corporations and governments are often diametrically opposed to citizens' interests and that some data sharing agreements can increase corporate or political elite power over society $[93,98]$. Therefore, B2G data sharing must follow democratic principles to align policy outcomes with popular needs.

Figure 1 illustrates those thoughts graphically and orientates this section's discussion along two key issues. First, are private data releases voluntary or enforced? In other words, do corporations share data when it suits their objectives and interests, or because they are compelled to do so by public legislation or civil society pressure? Second, who benefits from private data exchanges: political and corporate elites, or the public interest and civil society? Figure 1 shows four ideal types of data sharing arrangements determined by those two issues: (1) the activation mechanism for private data sharing, which may be voluntary or enforced, and (2) the net beneficiaries of private data releases, which may be corporate/political elites or the public/civil society. Figure 1 thus classifies data sharing schemes by incorporating issues of socio-economic power instead of technical and organisational criteria.

The $\mathrm{x}$-axis represents a continuum from data sharing arrangements that happen because corporations choose to release data voluntarily, to data sharing mechanisms that are enforced onto corporations. The y-axis measures whether, on balance, a data release benefits the public interest/civil society or corporate/state elites. The diagram's four quadrants correspond to four ideal types of data sharing schemes. Quadrant IV is a 'progressive' type containing data sharing arrangements whereby the state, local governments or city authorities successfully pressure corporations to release data for the public good. This can be accomplished by effective governments and a vibrant civil society. Conversely, quadrant II, 'corporate-driven regressive sharing', is somewhat the opposite: it denotes data releases that benefit elite interests and occur when companies share data 
on their own terms. Quadrant I, 'state-driven regressive sharing', refers to data sharing enforced on companies by the state but that benefits elites. Quadrant III, 'genuine data philanthropy', contains data sharing schemes whereby corporations choose to release data without significant advantage to themselves and that help to empower civil society or meet public interests.

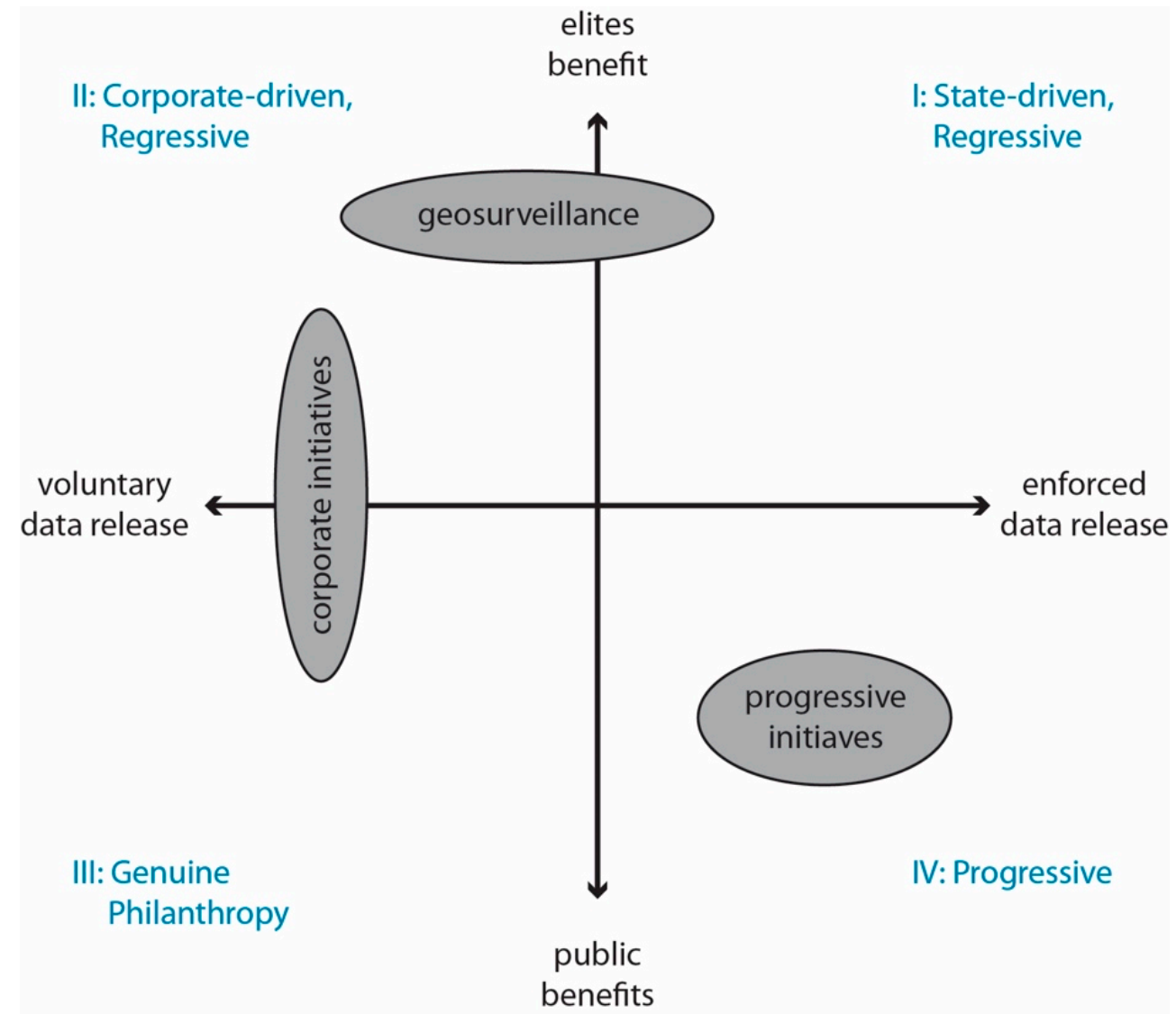

Figure 1. Four ideal types of private data sharing.

Consider the following empirical cases of data exchanges for each quadrant that further explain and illustrate the diagram's principles.

'Progressive data sharing' (quadrant IV): There are two main types of B2G data sharing in this category. First is what is sometimes called 'sharing data by regulation' [78] or 'data requisition' [34], which refers to obligatory data sharing requirements imposed by governments on companies in sectors like health, finance and pharmaceuticals. For instance, in Europe, the European Commission regulates for public sector bodies to have access to private entities' data when such data is deemed necessary to meet public objectives (e.g., national statistics) or to respond to emergencies (e.g., in public health or security) [77]. Examples include the Markets in Financial Instruments Directive 2 (MIFID2) that requires disclosing trading data to the public and transactions data to regulators and supervisors, as well as the Registration, Evaluation, Authorisation and Restriction of Chemicals (REACH) regulation, that requires firms to register chemicals with the European Chemical Agency (ECHA) [78]. Another important case in this category is that of National Statistical Agencies, which have spent much time and energy exploring ways to gain access to private sector data to assist them in creating richer statistical data $[84,85,99]$. There is a national trend in Europe whereby governments have compelled the private sector to release data, under certain conditions, to national statistical agencies, as does the recent French law for a digital Republic $[100,101]$.

The second type of progressive B2G sharing occurs in smart cities when city authorities facilitate or compel data sharing from private companies to be used to improve public 
services. However, a survey of B2G in 12 European cities concluded that local authorities getting access to private companies' data remains a 'sporadic' activity because firms tend to have little interest in sharing their data [80]. The survey outlined four ways in which European cities access commercial data. It should be noted that only the fourth one approximates an 'interventionist' approach to compel companies to share their data, while the first three depend largely on companies finding benefits in the arrangements: (1) data donorship involves firms voluntarily giving data, which they often do as part of a marketing strategy to promote their new products by showcasing them in smart cities; (2) public procurement of data means that cities have to pay companies to obtain their data, and so has limited potential because of cost and because companies often only make available limited datasets; (3) data partnerships seek to strike a 'win-win' relationship with companies to pool data; (4) data sharing clauses inserted within tender contracts with private suppliers allow data to be collected as a by-product. However, this latter method is only used by a small number of cities only, despite its potential to normalise B2G data sharing to cities' advantage. In fact, one strategy would be for cities in a country or in Europe to work together to agree on uniform contractual terms requiring data sharing from contracted companies so that the latter may not threaten to exit contracts and move elsewhere if contracts require substantial data sharing. The available evidence suggests that bigger and smarter cities may have an advantage to extract concessions from companies on data sharing because they offer larger markets and better marketing opportunities for new products [80].

'Corporate-driven regressive sharing' (quadrant II) and 'state-driven regressive sharing' (quadrant I): A key illustration located in either quadrants I and II is global or local surveillance, whereby governmental authorities, intelligence agencies, telecommunications and internet companies share data, which increases their power over society. A number of authors have pointed to the techniques of surveillance [102,103] utilised by the state in collaboration with telecoms and internet giants [30,104-106]. 'Surveillance studies' has become a growing field of interest among scholars, especially in the wake of the massive trove of intelligence documents leaked by National Security Agency (NSA) contractor Edward Snowden [107,108]. While these have illuminated the surveillance conducted by US intelligence and corporate entities, the 'surveillance-industrial complex' [109] has also manifested itself in Europe [110,111], including collaboration with US authorities [112]. An argument can be made that some forms of surveillance can benefit civil society [108], like ensuring that industrial installations are adequately monitored, but other types have exhibited over-reach. While surveillance may target criminals and terrorists, it may also be instrumental to conduct 'social sorting' whereby certain groups become targeted and policed, be it minorities, activists or dissidents like investigative journalists, pro-democracy individuals in authoritarian states, or anti-war protesters $[113,114]$. In any case, it is conducted in secrecy and reinforces the power of elites, not that of civil society.

Surveillance can result from companies' willingness to share data with state authorities (quadrant II), or from state intervention that compels corporations to release their data (quadrant I). Significantly, surveillance is an example of direct intervention by public authorities to extract data from private companies. It reveals that when the interests of political elites require data sharing from companies, they are willing and capable of enforcing data release. However, local/state governments have been more reluctant to use their power to extract private data from companies for the public good. This points to the nature of states under neoliberalism, which have been transformed and reshaped to align more closely with elite interests [115-119].

There are a number of illustrations. The 58,000 NSA documents leaked by Edward Snowden to journalists revealed that at the time of their reporting, the NSA processed over 20 billion communication events (including internet and telephone) around the world daily [112]. Snowden's leaks revealed three main types of data collection [114]. First, data-in-transit was intercepted, whereby the NSA accessed optical cables criss-crossing the globe carrying internet traffic. With the collaboration of local telecom companies, the 
United States could spy on individuals around the planet. The second type of surveillance involved access to stored data, through, for example, the PRISM programme. It allowed the NSA to access directly the servers of major internet companies including Apple, Facebook, Google, Microsoft, Yahoo, etc. Thirdly, data collection occurred by installing spyware directly onto physical computing devices like computers and routers (something the NSA referred to as 'Computer Network Exploitation').

The NSA entered into a number of 'corporate partnerships' with leading telecoms and internet giants. The existing evidence suggests that the companies were comfortable with sharing data with state authorities for surveillance. Sometimes, they were even eager to participate and put significant technical effort into making data readily accessible for the state, a practice located in quadrant II. For example, the Snowden documents revealed how Microsoft worked for many months to make its data easily available for government intelligence agencies [112]. Indeed, in the surveillance-industrial complex, public and private authorities work closely together and it becomes difficult to separate them neatly. There is, for example, a revolving door between private firms involved in surveillance and government agencies [114].

However, public authorities may also act proactively to compel companies to release their data, in cases located in quadrant I. Corporations have sometimes been reluctant to acquiesce to the state's request for extensive data access [120]. For example, Yahoo! vigorously fought in court the NSA's attempts to compel it to join PRISM (Yahoo! lost its case and was forced by a court to join PRISM). In 2008, the NSA threatened Yahoo! with fines of $\$ 250,000$ a day if it refused to share its data immediately [121,122]. Governments may even intervene to extract data surreptitiously from private firms. This happened when US and British spies in the NSA and GCHQ hacked the computer network of Gemalto, the largest manufacturer of SIM cards in the world. The spies stole the encryption keys that are used to secure global mobile phone communications. This allowed the United States and United Kingdom to monitor a large portion of global voice and data communications. Gemalto produces 2 billion SIM cards annually and operates in 85 countries; its clients include Verizon, Sprint, T-Mobile and AT\&T and some 450 wireless providers worldwide [123]. Gemalto was never aware that it had been hacked, and its leadership was 'quite disturbed' that this had happened when it learned about it due to reporting on the Snowden files, which contained the information [123]. Another example is the NSA's interception of computer equipment packages shipped from the United States to customers worldwide [112]. The NSA opened the packages before they left the United States, installed secret backdoor surveillance tools on the devices and repackaged them, so that when delivered, they tracked the purchaser's online actions and connected back to the NSA's infrastructure. There is no evidence that the manufacturers (e.g., Cisco) were aware of these practices before they were revealed by Snowden.

'Corporate-driven regressive sharing' (quadrant II) and 'genuine data philanthropy' (quadrant III): When corporations release data to the public voluntarily, they may do so out of self-interest through controlled releases that directly benefit their bottom line and with little public benefits (quadrant II). However, in other cases, data releases may be closer to 'genuine philanthropy' (quadrant III), when companies provide data to address humanitarian crises or challenges with little direct commercial benefits to them other than perhaps improving their corporate image. Assessing precisely where each case lies on the continuum requires detailed empirical examination outside the scope of this paper, but observations may be provided for purposes of illustration.

Data sharing schemes that benefit companies are common and their design tends to be influenced by the commercial interests of the firms releasing the data. For example, Googleowned Waze is a crowdsourced traffic and navigation platform that provides real-time information about incidents and slow-downs on the roads from drivers themselves. Waze partners with cities, government agencies and emergency services to share this information. However, an Urban Institute report states that 'many city planners are deeply skeptical of the ability of apps like Waze to benefit cities' [124] (p. 67). One problem is that Waze is an 
app designed to minimise drivers' commuting time by using any available road. In certain cities like Fremont, CA, Waze users began driving through small residential roads to avoid highway traffic. However, Waze told the city that the only way to fix the problem was to change traffic rules such as changing turning restrictions during certain hours, but this is likely only to shift the problem to other neighbourhoods.

Similarly, Yelp organizes an annual data challenge that consists in providing public access to its reviews and ratings data in order for researchers to compete by elaborating innovative uses of the data. Some of the winners constructed geospatial applications of the data, such as the project entitled 'Semantic Scan: Detecting Subtle, Spatially Localized Events in Text Streams' by a team from the University of Notre Dame and Carnegie Mellon University [125]. However, these challenges and the data released are closely controlled by Yelp and are based on a very small fraction of its data, and Yelp does not accept requests for additional data [124].

Other data sharing projects are less directly related to private interests, although commercial stakes are arguably always involved indirectly. For example, mobile phone location data donated to researchers by a phone company in Kenya has been used to assist the national malaria control program [126]. This was done by analysing mobile phone call data records that represent the travel patterns of 15 million people over a year. It was combined to a malaria risk map to estimate parasite movements within Kenya that could result from human movements. The analysis made it possible to identify sources and sinks of imported infections between hundreds of local settlements. Nevertheless, mobile phone companies' data releases usually come with several legal restrictions, including that data are only released to specific researchers, who must follow strict conditions for their use, publication, and sharing.

Additionally, Mastercard conducts data sharing initiatives under its Center for Inclusive Growth [127]. In one important project, it has shared data with a trusted partner (the Urban Institute in Washington, DC, USA) to study urban displacement caused by development projects that could lead to gentrification [83]. Mastercard used its residential cardholder zip codes to study cardholders' movements, for which available data were lacking. Last, Facebook's disaster maps are used with international development partners and first responders to know where people are, where they are going and where aid and resources should be targeted [124]. Facebook's Safety Check feature is shared with organisations like the Red Cross, UNICEF and the World Food Programme. Three types of map are provided to partners following a natural disaster: location density maps showing people's location before, during and after a disaster; movement maps between cities or neighborhoods following a disaster suggest evacuation routes taken by those affected; safety check maps showing where Facebook users have marked themselves safe.

\section{Conclusions}

This paper addressed B2G data sharing in smart cities and highlighted its potential to increase inclusiveness. As mentioned above, B2G data sharing and public-private partnerships or interactions are only one channel whereby inclusiveness may be fostered, and researchers have explored a range of alternative data governance practices that have the potential to democratise smart cities. With respect to B2G data sharing, there is a trend in existing research that focuses on voluntary data releases by corporate entities and that seeks to provide incentives to corporations to facilitate data sharing. However, companies can also be compelled to share their data, notwithstanding the costs they may incur in the process. In fact, cities and national governments have demonstrated that they have the capacity to intervene decisively to force corporate giants to share their data with public authorities as condition for private companies to operate within a city, with significant potential benefits for service delivery. These findings underline the usefulness of a critical approach to data sharing practices that pays attention to socio-economic power differentials instead of limiting analyses to technical and organisational aspects of data exchange.

One interesting next step in research would be to build on emerging work on data sharing that benefits citizens and communities (quadrant IV, Figure 1) whereby the public 
sector or civil society have compelled corporations to share their data for the public good and examine successes and failures in more depth. This is because they provide opportunities for smart cities to increase private data sharing for the public good that the other types of data sharing (quadrants I-III) are unable to provide. Indeed, the latter rely on corporations' goodwill, which has clear limits, and may produce outcomes that are detrimental to citizens' interests. Therefore, research could examine the factors that are conducive to data exchanges supporting inclusivenes and seek to theorise these sharing arrangements. For example, typologies of data sharing could be outlined to guide smart cities and civil society in their attempts to obtain privately-held data.

Funding: This research received no external funding.

Institutional Review Board Statement: Not applicable.

Informed Consent Statement: Not applicable.

Conflicts of Interest: The author declares no conflict of interest.

\section{References}

1. De Jong, M.; Joss, S.; Schraven, D.; Zhan, C.; Weijnen, M. Sustainable-smart-resilient-low carbon-eco-knowledge cities; making sense of a multitude of concepts promoting sustainable urbanization. J. Clean Prod. 2015, 109, 25-38. [CrossRef]

2. Lim, H.S.M.; Taeihagh, A. Algorithmic decision-making in AVs: Understanding ethical and technical concerns for smart cities. Sustainability 2019, 11, 5791. [CrossRef]

3. Tan, S.Y.; Taeihagh, A. Smart city governance in developing countries: A systematic literature review. Sustainability 2020, $12,899$. [CrossRef]

4. Bibri, S.E. The IoT for smart sustainable cities of the future: An analytical framework for sensor-based big data applications for environmental sustainability. Sust. Cities Soc. 2018, 38, 230-253. [CrossRef]

5. Bibri, S.E. On the sustainability of smart and smarter cities in the era of big data: An interdisciplinary and transdisciplinary literature review. J. Big Data 2019, 6, 25. [CrossRef]

6. Yigitcanlar, T.; Kamruzzaman, M.; Foth, M.; Sabatini-Marques, J.; da Costa, E.; Ioppolo, G. Can cities become smart without being sustainable? A systematic review of the literature. Sust. Cities Soc. 2019, 45, 348-365. [CrossRef]

7. Allam, Z. Cities and the Digital Revolution: Aligning Technology and Humanity; Palgrave Macmillan: London, UK, 2020.

8. Townsend, A.M. Smart Cities: Big Data, Civic Hackers, and the Quest for a New Utopia; WW Norton \& Company: New York, NY, USA, 2013.

9. Braun, T.; Fung, B.C.; Iqbal, F.; Shah, B. Security and privacy challenges in smart cities. Sust. Cities Soc. 2018, 39, 499-507. [CrossRef]

10. Allam, Z. The emergence of anti-privacy and control at the nexus between the concepts of safe city and smart city. Smart Cities 2019, 2, 96-105. [CrossRef]

11. Bass, T.; Sutherland, E.; Symons, T. Reclaiming the Smart City: Personal Data, Trust and the New Commons; European Commission: Brussels, Belgium, 2018.

12. Allam, Z.; Dhunny, Z.A. On big data, artificial intelligence and smart cities. Cities 2019, 89, 80-91. [CrossRef]

13. Cardullo, P.; Kitchin, R. Being a 'citizen'in the smart city: Up and down the scaffold of smart citizen participation in Dublin, Ireland. GeoJournal 2019, 84, 1-13. [CrossRef]

14. Cardullo, P.; Kitchin, R. Smart urbanism and smart citizenship: The neoliberal logic of 'citizen-focused'smart cities in Europe. Env. Plan. C Pol. Space 2019, 37, 813-830. [CrossRef]

15. Dalton, C.; Thatcher, J. What Does a Critical Data Studies Look Like, and Why Do We Care? Seven Points for a Critical Approach to 'Big Data'. Available online: https:/ / societyandspace.org/2014/05/12/what-does-a-critical-data-studies-look-like-and-whydo-we-care-craig-dalton-and-jim-thatcher/ (accessed on 10 July 2019).

16. Lee, J.Y.; Woods, O.; Kong, L. Towards more inclusive smart cities: Reconciling the divergent realities of data and discourse at the margins. Geog. Comp. 2020, 14, e12504. [CrossRef]

17. Vanolo, A. Is there anybody out there? The place and role of citizens in tomorrow's smart cities. Futures 2016, 82, 26-36. [CrossRef]

18. Caragliu, A.; Del Bo, C.; Nijkamp, P. Smart cities in Europe. J. Urb. Tech. 2011, 18, 65-82. [CrossRef]

19. Castelnovo, W.; Misuraca, G.; Savoldelli, A. Smart cities governance: The need for a holistic approach to assessing urban participatory policy making. Soc. Sci. Comp. Rev. 2016, 34, 724-739. [CrossRef]

20. Martin, C.; Evans, J.; Karvonen, A.; Paskaleva, K.; Yang, D.; Linjordet, T. Smart-sustainability: A new urban fix? Sust. Cities Soc. 2019, 45, 640-648. [CrossRef]

21. Meijer, A.; Bolívar, M.P.R. Governing the smart city: A review of the literature on smart urban governance. Int. Rev. Adm. Sci. 2016, 82, 392-408. [CrossRef]

22. Nesti, G. Defining and assessing the transformational nature of smart city governance: Insights from four European cases. Int. Rev. Adm. Sci. 2020, 86, 20-37. [CrossRef] 
23. Alemanno, A. Big Data for Good: Unlocking Privately-Held Data to the Benefit of the Many. Eur. J. Risk Reg. $2018,9,183-191$. [CrossRef]

24. Fuchs, C. Labor in Informational Capitalism and on the Internet. Info. Soc. 2010, 26, 179-196. [CrossRef]

25. Kitchin, R. The Data Revolution: Big Data, Open Data, Data Infrastructures and Their Consequences; Sage: London, UK, 2014.

26. Kitchin, R.; Lauriault, T. Data and Data Infrastructures. In Digital Geographies; Ash, J., Kitchin, R., Leszczynski, A., Eds.; Sage: Thousand Oaks, CA, USA, 2018.

27. Ruppert, E.; Isin, E.; Bigo, D. Data politics. Big Data Soc. 2017, 4, 1-7. [CrossRef]

28. Schiller, D. Digital Capitalism: Networking the Global Market System; MIT press: Cambridge, MA, USA, 1999.

29. Srnicek, N. Platform Capitalism; Polity: Milton, Australia, 2017.

30. Zuboff, S. The Age of Surveillance Capitalism: The Fight for a Human Future at the New Frontier of Power; Hachette/PublicAffairs: New York, NY, USA, 2019.

31. Aitken, R. 'All data is credit data': Constituting the unbanked. Comp. Chang. 2017, 21, 274-300. [CrossRef]

32. Andrejevic, M. The Big Data Divide. Int. J. Comm. 2014, 8, 1673-1689.

33. Fourcade, M.; Healy, K. Seeing like a market. Soc. Econ. Rev. 2017, 15, 9-29. [CrossRef]

34. Carballa Smichowski, B. Alternative data governance models: Moving beyond one-size-fits-all solutions. Intereconomics 2019, 54, 222-227. [CrossRef]

35. Calzada, I. Smart City Citizenship; Elsevier: Amsterdam, The Netherlands, 2021.

36. Calzada, I. Platform and Data Co-Operatives amidst European Pandemic Citizenship. Sustainability 2020, 12, 8309. [CrossRef]

37. Micheli, M.; Ponti, M.; Craglia, M.; Berti Suman, A. Emerging models of data governance in the age of datafication. Big Data Soc. 2020, 7, 1-15. [CrossRef]

38. Susha, I.; Gil-Garcia, J.R. A Collaborative Governance Approach to Partnerships Addressing Public Problems with Private Data. In Proceedings of the 52nd Hawaii International Conference on System Sciences, Maui, HI, USA, 8-11 January 2019.

39. Hardjono, T.; Pentland, A. Data cooperatives: Towards a foundation for decentralized personal data management. arXiv 2019, arXiv:1905.08819.

40. Ho, C.-H.; Chuang, T.-R. Governance of Communal Data Sharing. In Good Data; Daly, A., Devitt, S.K., Mann, M., Eds.; Institute of Network Cultures: Amsterdam, The Netherlands, 2019; pp. 202-213.

41. Verhulst, S.; Sangokoya, D. Data Collaboratives: Exchanging Data to Improve People's Lives. Available online: https://medium. com/@sverhulst/data-collaboratives-exchanging-data-to-improve-people-s-lives-d0fcfc1bdd9a (accessed on 13 February 2019).

42. Susha, I.; Janssen, M.; Verhulst, S. Data collaboratives as a new frontier of cross-sector partnerships in the age of open data: Taxonomy development. In Proceedings of the 50th Hawaii International Conference on System Sciences, Hilton Waikoloa Village, HI, USA, 4-7 January 2017; pp. 2691-2700.

43. Borkin, S. Platform Co-Operatives—Solving the Capital Conundrum; NESTA: London, UK, 2019.

44. Como, E.; Mathis, A.; Tognetti, M.; Rapisardi, A. Cooperative Platforms in a European Landscape: An Exploratory Study; ISIRC: Glasgow, Scotland, 2016.

45. McCann, D.; Yazici, E. Disrupting Together: The Challenges (and Opportunities) for Platform Co-Operatives; New Economics Foundation and Nesta: London, UK, 2018.

46. Sandoval, M. Entrepreneurial activism? Platform cooperativism between subversion and co-optation. Crit. Soc. 2020, 46, 801-817. [CrossRef]

47. Schneider, N. An Internet of ownership: Democratic design for the online economy. Soc. Rev. 2018, 66, 320-340. [CrossRef]

48. Scholz, T. Platform Cooperativism: Challenging the Corporate Sharing Economy; Rosa Luxemburg Foundation: New York, NY, USA, 2016.

49. Scholz, T.; Schneider, N. Ours to Hack and to Own: The Rise of Platform Cooperativism, a New Vision for the Future of Work and a Fairer Internet; OR Books: New York, NY, USA, 2017.

50. Delacroix, S.; Lawrence, N.D. Bottom-up data Trusts: Disturbing the 'one size fits all'approach to data governance. Int. Data Priv. Law 2019, 9, 236-252. [CrossRef]

51. Hall, W.; Pesenti, J. Growing the Artificial Intelligence Industry in the UK; Department for Digital, Culture, Media \& Sport and Department for Business, Energy \& Industrial Strategy. Part of the Industrial Strategy UK and the Commonwealth: London, UK, 2017.

52. Hardinges, J. What Is a Data Trust? Available online: https://theodi.org/article/what-is-a-data-trust/\#1527169770610-7c7f3670046362d2-2d92 (accessed on 2 February 2021).

53. Kirkpatrick, R. Big Data for Development. Big Data 2013, 1, 3-4. [CrossRef]

54. Susha, I.; Pardo, T.A.; Janssen, M.; Adler, N.; Verhulst, S.G.; Harbour, T. A Research Roadmap to Advance Data Collaboratives Practice as a Novel Research Direction. Int. J. Electron. Gov. Res. 2018, 14, 1-11. [CrossRef]

55. Noveck, B.S. Data Collaboratives: Sharing Public Data in Private Hands for Social Good; Forbes: Jersey City, NJ, USA, 24 September 2015.

56. Howard, A. Data for the Public Good; O'Reilly Media: Sebastopol, CA, USA, 2012.

57. Calzada, I. (Smart) Citizens from Data Providers to Decision-Makers? The Case Study of Barcelona. Sustainability 2018, 10, 3252. [CrossRef]

58. Calzada, I. Deciphering smart city citizenship: The techno-politics of data and urban co-operative platforms. Int. J. Basqu. Stud. Rev. Int. Estud. Vascos 2019, 63, 42-81. 
59. Calzada, I.; Almirall, E. Data ecosystems for protecting European citizens' digital rights. Transform. Gov. People Process. Policy 2020, 14, 133-147. [CrossRef]

60. Calzada, I.; Almirall, E. Barcelona's grassroots-led urban experimentation: Deciphering the 'data commons' policy scheme. In Proceedings of the Data for Policy 2019 International Conference, London, UK, 11-12 June 2019.

61. Morozov, E.; Bria, F. Rethinking the smart city. In Democratizing Urban Technology; Rosa Luxemburg Foundation: New York, NY, USA, 2018; Volume 2.

62. Calzada, I. Technological sovereignty: Protecting citizens' digital rights in the AI-driven and post-GDPR algorithmic and city-regional European realm. Regions eZine 2019. [CrossRef]

63. Valencia, J.-C.; Restrepo, P. Truly Smart Cities. Buen Conocer, Digital Activism and Urban Agroecology in Colombia. In Good Data; Daly, A., Devitt, S.K., Mann, M., Eds.; Institute of Network Cultures: Amsterdam, The Netherlands, 2019 ; pp. $317-329$.

64. Bastani, A. Fully Automated Luxury Communism; Verso Books: London, UK, 2019.

65. Bigo, D.; Isin, E.; Ruppert, E. (Eds.) Data Politics: Worlds, Subjects, Rights; Routledge: London, UK, 2019.

66. Ilves, L.K.; Osimo, D. A Roadmap for a Fair Data Economy; Lisbon Council and Sitra: Lisbon, Portugal, 2019.

67. Wong, P.-H. Democratizing algorithmic fairness. Phil. Tech. 2020, 33, 225-244. [CrossRef]

68. Baack, S. Datafication and empowerment: How the open data movement re-articulates notions of democracy, participation, and journalism. Big Data Soc. 2015, 2, 1-11. [CrossRef]

69. Beraldo, D.; Milan, S. From data politics to the contentious politics of data. Big Data Soc. 2019, 6, 1-11. [CrossRef]

70. Couldry, N.; Powell, A. Big data from the bottom up. Big Data Soc. 2014, 1, 1-5. [CrossRef]

71. DiEm25. Technological Sovereignty: Democratising Technology and Innovation; DiEM25: Brussels, Belgium, 2019.

72. Kennedy, H.; Moss, G. Known or knowing publics? Social media data mining and the question of public agency. Big Data Soc. 2015, 2, 1-11. [CrossRef]

73. Kennedy, H.; Poell, T.; Van Dijck, J. Data and agency. Big Data Soc. 2015, 2, 1-7. [CrossRef]

74. Symons, T.; Bass, T. Me, My Data and I: The Future of the Personal Data Economy; European Commission: Brussels, Belgium, 2017.

75. Mann, M.; Devitt, S.K.; Daly, A. What Is (in) Good Data? In Good Data; Daly, A., Devitt, S.K., Mann, M., Eds.; Institute of Network Cultures: Amsterdam, The Netherlands, 2019; pp. 8-23.

76. GovLab. Data Collaboratives Explorer. Available online: http:/ / datacollaboratives.org/explorer.html (accessed on 18 July 2021).

77. High-Level Expert Group. Towards a European Strategy on Business-To-Government Data Sharing for the Public Interest. Final report prepared by the High-Level Expert Group on Business-to-Government Data Sharing; European Union: Luxembourg, 2020.

78. Huyer, E.; Cecconi, G. Analytical Report 12: Business-to-Government Data Sharing; European Data Portal: Brussels, Belgium, March 2019.

79. Keller, J.R. Data Access Archipelago: Mapping the Myriad Ways We Share Data. Available online: https://theodi.org/article/ data-access-archipelago-mapping-the-myriad-ways-we-share-data/ (accessed on 17 February 2019).

80. Micheli, M. Commercial Sector Data for the Public Interest? A Qualitative Research on Data Sharing Practices in EU Cities. In Digitranscope; The Governance of Digitally-Transformed Society; Craglia, M., Scholten, H., Micheli, M., Hradec, J., Calzada, I., Luitjens, S., Ponti, M., Boter, J., Eds.; Publications Office of the European Union: Luxembourg, 2021; pp. 95-108.

81. Shkabatur, J. The global commons of data. Stan. Tech. L. Rev. 2019, 22, 354.

82. Keller, J.R.; Chauvet, L.; Fawcett, J.; Thereaux, O. The Role of Data in AI Business Models; Open Data Institute: London, UK, 2018.

83. McKeever, B.; Greene, S.; MacDonald, G.; Tatian, P.; Jones, D. Data Philanthropy: Unlocking the Power of Private Data for Public Good; Urban Institute: Washington, DC, USA, July 2018.

84. Robin, N.; Klein, T.; Jütting, J. Public-Private Partnerships for Statistics: Lessons Learned, Future Steps; OECD: Paris, France, February 2016.

85. Klein, T.; Verhulst, S. Access to New Data Sources for Statistics: Business Models and Incentives for the Corporate Sector; OECD: Paris, France, 2017.

86. Verhulst, S.; Sangokoya, D. Mapping the Next Frontier of Open Data: Corporate Data Sharing. In Internet Monitor 2014: Reflections on the Digital World: Platforms, Policy, Privacy, and Public Discourse; Grasser, U., Zittrain, J., Faris, R., Heacock Jones, R., Eds.; Berkman Center for Internet \& Society Research: Cambridge, MA, USA, 2014; pp. 72-76.

87. Verhulst, S.; Young, A.; Srinivasan, P. An Introduction to Data Collaboratives: Creating Public Value by Exchanging Data; GovLab, Unicef, Omidyar Network: New York, NY, USA, 2017.

88. Martens, B.; Duch-Brown, N. The Economics of Business-to-Government Data Sharing. Joint Research Centre Technical Report. JRC119947; European Commission: Seville, Spain, 2020.

89. Susha, I.; Grönlund, Å.; Van Tulder, R. Data driven social partnerships: Exploring an emergent trend in search of research challenges and questions. Gov. Inform. Q. 2019, 36, 112-128. [CrossRef]

90. European Commission. Towards a Common European Data Space COM(2018) 232 Final; European Commission: Brussels, Belgium, 25 April 2018.

91. European Commission. Guidance on Sharing Private Sector Data in the European Data Economy, SWD(2018) 125 Final; European Commission: Brussels, Belgium, 25 April 2018.

92. Jarman, H.; Luna-Reyes, L.F. (Eds.) Private Data and Public Value: Governance, Green Consumption, and Sustainable Supply Chains; Springer: New York, NY, USA, 2016.

93. Mann, L. Left to Other Peoples' Devices? A Political Economy Perspective on the Big Data Revolution in Development. Dev. Chang. 2018, 49, 3-36. [CrossRef]

94. Stempeck, M. Sharing Data Is a Form of Corporate Philanthropy. Harvard Business Review, 24 July 2014. 
95. Harris, L.; Sharma, C. Understanding Corporate Data Sharing Decisions: Practices, Challenges, and Opportunities for Sharing Corporate Data with Researchers; Future of Privacy Forum: Washington, DC, USA, November 2017.

96. Mazzucato, M. The Entrepreneurial State: Debunking Public Vs. Private Sector Myths; Anthem Press: London, UK, 2013 ; Volume 1.

97. Mazzucato, M. Mission-oriented innovation policies: Challenges and opportunities. Ind. Corp. Chang. 2018, 27, 803-815. [CrossRef]

98. Johnson, P.A.; Sieber, R.; Scassa, T.; Stephens, M.; Robinson, P. The cost (s) of geospatial open data. Trans. GIS 2017, 21, 434-445. [CrossRef]

99. Reimsbach-Kounatze, C. The Proliferation of "Big Data" and Implications for Official Statistics and Statistical Agencies; OECD: Paris, France, 2015.

100. European Commission. Data Access for Official Statistics; European Commission: Brussels, Belgium, June 2017.

101. Government, F. Loi 2016-1321 du 7 October 2016 Pour une République Numérique. Available online: https:/ / www.legifrance. gouv.fr/eli/loi/2016/10/7/ECFI1524250L/jo/texte (accessed on 11 July 2019).

102. Crampton, J.W. Collect it all: National security, big data and governance. GeoJournal 2015, 80, 519-531. [CrossRef]

103. Swanlund, D.; Schuurman, N. Mechanism matters: Data production for geosurveillance. Ann. Ass. Am. Geog. 2016, 106, 1063-1078. [CrossRef]

104. Foster, J.B.; McChesney, R.W. Surveillance capitalism: Monopoly-finance capital, the military-industrial complex, and the digital age. Mon. Rev. 2014, 66. [CrossRef]

105. McChesney, R.W. Digital Disconnect: How Capitalism is Turning the Internet against Democracy; The New Press: New York, NY, USA, 2013.

106. Zuboff, S. Big other: Surveillance capitalism and the prospects of an information civilization. J. Inform. Tech. 2015, 30, 75-89. [CrossRef]

107. Lyon, D. Surveillance, Snowden, and big data: Capacities, consequences, critique. Big Data Soc. 2014, 1, 1-13. [CrossRef]

108. Marx, G. Surveillance Studies. In International Encyclopedia of the Social \& Behavioral Sciences, 2nd ed.; Wright, J., Ed.; Elsevier: Amsterdam, The Netherlands, 2015; Volume 23, pp. 733-741.

109. Ball, K.; Snider, L. The Surveillance-Industrial Complex: A Political Economy of Surveillance; Routledge: London, UK; New York, NY, USA, 2013.

110. Hayes, B. "Full Spectrum Dominance" as European Union Security Policy: On the trail of the "NeoConOpticon". In Surveillance and Democracy; Haggerty, K.D., Samatas, M., Eds.; Routledge: London, UK, 2010; pp. 148-170.

111. Wright, D.; Kreissl, R. (Eds.) Surveillance in Europe; Routledge: London, UK, 2015.

112. Greenwald, G. No Place to Hide: Edward Snowden, the NSA, and the US Surveillance State; Metropolitan Books: New York, NY, USA, 2014.

113. Fuchs, C.; Trottier, D. Towards a theoretical model of social media surveillance in contemporary society. Commun. Ger 2015, 40, 113-135. [CrossRef]

114. Lyon, D. Surveillance after Snowden; Polity: Cambridge, MA, USA, 2015.

115. Brenner, N.; Peck, J.; Theodore, N. Variegated neoliberalization: Geographies, modalities, pathways. Glob. Net. 2010, 10, 182-222. [CrossRef]

116. Harvey, D. A Brief History of Neoliberalism; Oxford University Press: New York, NY, USA, 2005.

117. Mercille, J.; Murphy, E. Market, non-market and anti-market processes in neoliberalism. Crit. Sociol. 2019, 45, 1093-1109. [CrossRef]

118. Mercille, J.; Murphy, E. Conceptualising European Privatisation Processes After the Great Recession. Antipode 2016, 48, 685-704. [CrossRef]

119. Mercille, J.; Murphy, E. What is privatization? A political economy framework. Environ. Plann. A 2017, 49, 1040-1059. [CrossRef]

120. Miller, C.C. Secret Court Ruling Put Tech Companies in Data Bind. New York Times, 13 June 2013.

121. Goel, V.; Savage, C. Government's Threat of Daily Fine for Yahoo Shows Aggressive Push for Data. New York Times, 11 September 2014.

122. Miller, C.C. Tech Companies Concede to Surveillance Program. New York Times, 7 June 2013.

123. Scahill, J.; Begley, J. How Spies Stole the Keys to the Encryption Castle. The Intercept, 19 February 2015.

124. Verhulst, S.; Young, A. The Potential of Social Media Intelligence to Improve People's Lives: Social Media for Good; GovLab: Brooklyn, NY, USA, 2017.

125. Maurya, A.; Murray, K.; Liu, Y.; Dyer, C.; Cohen, W.W.; Neill, D.B. Semantic scan: Detecting subtle, spatially localized events in text streams. arXiv Prepr. 2016, arXiv:1602.04393.

126. Wesolowski, A.; Eagle, N.; Tatem, A.J.; Smith, D.L.; Noor, A.M.; Snow, R.W.; Buckee, C.O. Quantifying the impact of human mobility on malaria. Science 2012, 338, 267-270. [CrossRef] [PubMed]

127. Mastercard Mastercard Center for Inclusive Growth. Available online: https://www.mastercardcenter.org/ (accessed on 13 February 2021). 